spent the previous five days in strenuous University work. He was also chairman of the Timber Mechanics Committee, and so recently as July 1934 that Committee issued a report, largely the work of Ewing himself. There can be little doubt that Ewing habitually overworked himself during the last three or four years of his life-work was his passion, especially research work, and it was to research work that he devoted his main energies during his last years.

It is interesting to remember that, as Ewing began his university career and his life's work more than sixty years ago in the engineering class-room of the University of Edinburgh, so he made his last public appearance in the lecture room of the engineering department only last October, when he delivered an address entitled "For Better or Worse" to the members of the Associated Science Societies of the University. How much he was beloved by the students of the University was attested by the fact that he was known to them by the affectionate nickname of "Alfy", and, at the conclusion of his last address, after the formal vote of thanks had been proposed and carried, the student audience rose to its feet and gave, as only students can, three rousing cheers for "Alfy".

Ewing's last years were largely occupied by the thought that man's ethical development had not kept pace with the advance of science, that science and engineering had placed in the hands of mankind tools which man had not yet learned to use wisely. This formed the main theme of his remarkable presidential address to the British Association for the Advancement of Science at York in 1932. In "An Engineer's Outlook", published two years ago, one of the reprinted lectures was the Hibbert Lecture, delivered at the University of Cambridge in February 1933, on "Science and some Modern Problems". This lecture summed up Ewing's creed; after sixty years of active life in the service of education and science, he could find no better principle to urge on his listeners than the old gospel of goodwill"Thou shalt love thy neighbour"- this, he said, is not a mere general injunction, it is an individual message.

Ewing was the recipient of many honours. He held honorary degrees of the Universities of Oxford, Cambridge, Durham and St. Andrews. $\mathrm{He}$ was elected a fellow of the Royal Society in 1887, and in 1895 received a Royal Medal for his researches on magnetism. He was elected an honorary member of the Institution of Civil Engineers in 1929, and of the Institution of Mechanical Engineers in 1932. He was made a Companion of the Bath in 1907, and Knight Commander of the same order in 1911. He was the author of many papers on scientific subjects, published in the Transactions of the Royal Society and other scientific societies. His textbooks include "Magnetic Induction in Iron and Other Metals"; "The Steam Engine and Other Heat Engines", of which many editions have been issued, and which has been translated into many languages; "The Mechanical Production of Cold", "Thermodynamics for Engineers" and "The Strength of Materials".

T. Hudson Beare.

\section{Sir Alfred Ewing and his Cambridge Chair}

The Jacksonian professorship of natural and experimental philosophy at Cambridge is an old foundation dating from 1783. It was the duty of the professor to give experimental lectures on "Natural Experimental Philosophy and Chymistry", and the chair had been held by a succession of distinguished men. In 1875 it was vacant through the death of Prof. Willis, who had been its occupant for nearly forty years. His predecessors had been chemists.

By 1875 it was recognised that the study of the natural sciences deserved fuller encouragement. Maxwell, a few years previously, had been appointed to the chair of physics. Foster was lecturing as a Trinity prælector, Frank Balfour was beginning his work on comparative anatomy, and Liveing was teaching chemistry to an ever-increasing number of students. It was clear that he needed help; the Jacksonian professorship again became a chemical chair and Dewar was invited to fill it.

At the same time, it was felt that mechanism and applied mechanies should still have a place in the University course; there was a man in Cambridge who could carry on some part at least of Willis's work, and so a professorship of mechanism and applied mechanics, to "terminate with the tenure of office of the professor first elected" unless the University should determine otherwise, was established, and James Stuart became professor. There were some, Coutts Trotter for example, who, even then, sixty years ago, realised that the scientific study of engineering was a fitting subject for inclusion in the scheme of an ancient university. It was a long step from this appointment to a professorship of engineering. It was to be the duty of the professor to lecture on the principles of mechanism; the theory of structures; the theory of machines including the steam engine and other prime movers.

There was an ordinary degree in mechanism and applied science, for which students were advised to read parts of Weale's Rudimentary Series, Balfour Stewart's "Heat", Bird and Brooke's "Elements of Natural Philosophy", and Ganot's "Physics". There was no laboratory, no provision for experimental work. But the professor started his work He raised funds for a certain amount of apparatus, some tools and workshop appliances, which ultimately were taken over by the University. A shed was erected to hold these, and by slow degrees the work grew.

Some ten years later (1886-87), there was much controversy as to the place workshops should hold in a scheme for an honours degree in engineering then under discussion. A syndicate appointed to investigate among other things the "whole question of the workshops" was granted, in 1890, "further powers to enquire whether it be desirable to develop further the Engineering School in the University on the lines suggested" in a memorandum it had issued, and as a result, on November 10, 1892, the Mechanical Sciences Tripos was established. The Tripos was to be in two parts covering the usual subjects of examination for an honours degree in engineering, together 
with-an addition of 1895-a paper of essays having "reference to the fundamental principles, history, philosophy or applications of the Mechanical Sciences".

Meanwhile, Prof. Stuart had resigned and, to quote the "University Calendar", in "1890 J. A. Ewing, B.Sc. Edinb." had been appointed professor. He came, personally unknown to us, but with a distinguished career as a teacher at Tokyo and Dundee, a pupil of Lord Kelvin, the author of papers on magnetism of outstanding merit. In 1881 he had described the effects which follow the application of a cyclical process of magnetisation to iron and other material, that tendency of the magnetisation to lag behind the application of the magnetising force, to which he gave the name of hysteresis, and in 1885 had contributed a striking paper to the Royal Society entitled "Experimental Researches in Magnetism".

Ewing established himself at once as a persona grata to the University, a colleague, soon to be our leader, whom some of us who had been active in urging that engineering should receive full recognition from the University welcomed whole-heartedly among our ranks. To his wise judgment and sane advice are due the general acceptance of the scheme of education proposed. The debt due to him by the University may perhaps be measured by the success of that scheme which, aided by his staff, Peace and Dalby and Lamb, he developed for the next thirteen years.

A committee was set up in Cambridge to obtain funds for the establishment of an adequate laboratory for the teaching of engineering in the University. Sir J. J. Thomson, Prof. Newall, Sir Napier Shaw and myself are the sole survivors. Ewing was the treasurer. We had the help of a large and distinguished general committee which contained the names of all the great engineers of the day. We stated that $£ 20,000$ would be required for the complete design, but that much could be done for $£ 4,000$ or $£ 5,000$, and with the money so raised the Engineering Laboratory made its start. What it has now become engineers are well aware.

The first Tripos examination was held in 1896, Ewing, Osborne Reynolds, and Shaw were the examiners; seven candidates passed, of whom three were placed in the first class. Now the Engineering Tripos list is among the largest in the University.

Since those days, Sir Alfred has done more great work for his country. In Cambridge he will ever be remembered as the founder of the Engineering School, the man who taught the University what science, so long at home there, might do for industry and how that task might be achieved.

R. T. Glazebrook.

\section{Sir Alfred Ewing and Naval Education}

The connexion of Sir Alfred Ewing with naval education came about through the decision of the Admiralty, in 1902, to carry out a root and branch reform of the training of officers and men in all sections of the Navy. The reform was long overdue, for even up to 1901, junior officers spent a part of their time in learning to manœuvre ships under sail, although for all practical purposes sails in warships had been obsolete for thirty years. Then, too, there was the urgent problem of the staffing of the engine rooms of the steadily increasing fleet, a problem rendered difficult by the failure of successive Boards of Admiralty to adjust the status of naval engineers in accordance with their responsibilities.

Though at the beginning of the century, naval training was discussed in many quarters, the credit for the re-organisation of naval education in 1903 to meet modern requirements belongs in the first place to Lord Fisher (then Admiral Sir John Fisher), who had recently become First Sea Lord. The first step in the reform was the publication in December 1902, over the signature of Lord Selborne, of the famous "Memorandum dealing with the Entry, Training and Employment of Officers and Men of the Royal Navy and of the Royal Marines". That memorandum stated that "In the old days it sufficed if a naval officer were a seaman; now he must be a seaman, a gunner, a soldier, an engineer, and a man of science as well"; and that "the three branches of the Service which are essential to the fighting efficiency of the Fleet-the Executive, the Engineer and the Marine" were to be recruited by one system and all officers were to be trained alike up to a certain age.

These were ideas entirely new to the Service and to carry them into effect it was obvious that the Admiralty would require a man of outstanding reputation. Their choice fell on Sir Alfred Ewing, who in the preface to his book, "An Engineer's Outlook", tells of his first visit to the Admiralty, when he met Lord Fisher, "that volcanic personality whom, later, I was to see often in quiescence and in eruption, and to learn something of his greatness". This visit led to Lord Selborne offering Sir Alfred the appointment of Director of Naval Education.

To a civilian, the task Sir Alfred undertook might well have appeared a complex one, for in the course of a few months he found himself responsible for the training given in the Royal Naval College, Greenwich, H.M.S. Britannia, the new Royal Naval College at Osborne, the Royal Naval Engineering College at Keyham, the Dockyard Schools at Portsmouth, Chatham and Devonport, various training establishments for seamen, stokers and artificers, together with the supervision of the work of some eighty naval instructors of university standing, many of whom were serving on distant stations. The SelborneFisher scheme naturally cut across many traditions and found not a few critics; while from the members of the Board of Admiralty Sir Alfred received every assistance, among those below them he was sometimes conscious of cross-currents.

From the beginning it was realised that the new system of training would have to be modified in the light of experience, and many changes have been made. It may, however, safely be said that naval education to-day owes more to the work done by Sir Alfred Ewing between 1903 and the War than to any other single individual.

Edgar C. SMith. 